Volume 2, Number 1, 2016

\title{
Determination of Wood Fractional Composition Effect on Gasification Process
}

\author{
Stepan Lys ${ }^{*}$, Yosyph Mysak, Taras Kravets \\ Lviv Polytechnic National University, 12, S. Bandery St., Lviv, 79013, Ukraine
}

Received: October 01, 2016. Revised: October 07, 2016. Accepted: December 23, 2016

(C) 2016 The Authors. Published by Lviv Polytechnic National University.

\begin{abstract}
The heating value of synthesis gas derived as a result of the fuel gasification can vary depending on various factors. The main factors that affect the process of gasification is the fractional composition of wood; the amount of air fed to the gasification chamber; the height of the active layer and a series of other factors, dependent on fuel which is gasified and parameters of the gasifier. Any type of wood has to be to ground up for subsequent thermal processing. Depending on the production necessity, wood is ground up to technological chips of different fractions by chipping machines (also called wood chippers, shredder). The choice of chippers type depends on the need. Modern chipping machines allow making fine tuning of the source material by wood size. Considering the deficit and cost of energy carriers to the forefront using waste of wood chippers as fuel for gas-generator installations and solid fuel boilers.

Keywords: calorific value of synthesis gas; gas-generators installation; wood gasification process; fractional composition of wood.

\section{Formulation of the problem}

Physical and mechanical properties of chopped wood, except bulk weight, are no different from the properties of wood. The main difference of any loose material on the whole lies in the discrete nature of its particles (sawdust, shavings, speck of dust). In this connection, weshould consider the physical and mechanical properties of individual particles and properties of the whole mass of the loose material. The moisture in the wood affects the physical and mechanical properties of wood in any of its kind. Even at higher wood moisture content of 14-16\% water acts as a lubricant at a given mechanical impact, especially during fragmentation and crushing when the pieces or particles are relatively large. At very low moisture content of wood (less than $4.5 \%$ ), water forms thin films in wood thickness. In this state, the wood becomes brittle, breaks easily and is easily shredded [1,2]. At various operations with loose waste, we have to count certain other technical processes such as gasification, burning, etc.
\end{abstract}

\section{Analysis of recent research and publications}

In the process of gasification or burning of wood, particles size plays an important role. For calculations convenience and simplification, loose materials particles form is supposed to be spherical. In fact loose particles of wood differ in form from the sphere. Therefore the concept of equivalent diameter is introduced, i.e. linear particle size, equivalent to the diameter of the respective sphere.

The equivalent diameter of particles is determined by sieve analysis [1] as follows:

$$
d_{e}=\frac{\sum_{i=1}^{i=k} x_{i} d_{i}}{\sum_{i=1}^{i=k} x_{i}}
$$

where $d_{i}$ is average sieve holes diameter; $k$ is number of primary fractions in the layer on dispersion size; $x_{i}$ is mass share of the fraction;

\footnotetext{
*Corresponding author. Email address: stepan.s.lys@1pnu.ua
} 
The average diameter $d_{i}$ is defined by the formula

$$
d_{i}=\sqrt{\frac{d_{1}^{2} d_{2}^{2}}{d_{1}+d_{2}}},
$$

where $d_{1}$ and $d_{2}$ are determined in accordance with the size of holes of passable and impassable sieves.

If the particle sizes are determined experimentally and they are very different in form from the sphere, the equivalent diameter of the particles can be determined by the formula:

$$
d_{e}=\varphi \cdot d_{\kappa}
$$

where $\varphi$ is factor or form factor; $d_{\kappa}$ is diameter sphere, the amount of which is equivalent to the volume of the particle.

If the volume of the particles is equal to $V_{p}$, then when $V_{\kappa}=V_{p}$ diameter sphere is equal to

$$
d_{\kappa}=\sqrt{\frac{V_{p}}{0,524}} .
$$

For spherical particles $\varphi=1$, round $\varphi=0.75$, shapeless $\varphi=0.66$, oblong $\varphi=0.58$, lamellar $\varphi=0.43$.

Taking into account the fractional composition and amount of wood needed in this technological process, we choose a PM-5P shredder. Shredder is equipped with a pneumatic conveyor or belt conveyor for the removal of chips, grinding device, control device to resize chips (chips size is adjustable - length from $10 \mathrm{~mm}$ to $40 \mathrm{~mm}$, width $7 \mathrm{~mm}$ to $20 \mathrm{~mm}$ thickness from $1.5 \mathrm{~mm}$ to $5 \mathrm{~mm}$ ).

\section{Aim of the research}

The research is aimed at studying the effect of chopped wood particle size on gasification process and a lower calorific value of synthesis gas.

\section{Results of the research}

Analysis of the impact of input parameters, one of which is the fractional composition of wood, the calorific value of synthesis gas will help us find optimal regime parameters for gasification and laboratory gas generator, which allows developing technology for the gasification process and the constructive scheme for the industrial gas generator installation.

For the experimental research and the development of wood gasification process into gaseous fuel, a gasifier with a continuous layer has been designed [3].

The problem was to find dependence of lower synthesis gas calorific value on particle size of the chopped wood supplied to the gasifier, the amount of air and the amount of fuel in the gasification chamber.

In order to establish the nature of the variable factors influence on net calorific value of synthesis gas, the threelevel plan $\left(\mathrm{B}_{3}\right)$ [5-7] was Used. Levels and intervals of factors change are shown in the Table 1.

Table 1. Levels and intervals of factors change

\begin{tabular}{|c|c|c|c|c|c|c|}
\hline \multirow{2}{*}{ Factors } & \multicolumn{2}{|c|}{ Factor designation } & \multicolumn{2}{|c|}{ Levels of factor changing } & \multirow{2}{*}{ Interval of factor changing } \\
\cline { 2 - 6 } & natural & normalized & $(-1)$ & $(0)$ & $(+1)$ & 20 \\
\hline Size of the wood particles, $\mathrm{mm}$ & $l$ & $\mathrm{x}_{1}$ & 10 & 30 & 50 & 25 \\
\hline Amount of air, $\mathrm{nm}^{3} / \mathrm{hr}$ & $G$ & $\mathrm{x}_{2}$ & 40 & 65 & 90 & 25 \\
\hline Amount of fuel in the gasifier reactor, $\%$ & $q$ & $\mathrm{x}_{3}$ & 50 & 75 & 100 & 25 \\
\hline
\end{tabular}

It has been established that the highest calorific value of synthesis gas is reached during the gasification of wood with a particle size of $30 \mathrm{~mm}$ (Fig. 1), the amount of air $65 \mathrm{~nm}^{3} / \mathrm{hr}$, fed into the gasification chamber, and the amount of fuel $75 \%$ of the total volume of the reactor. 


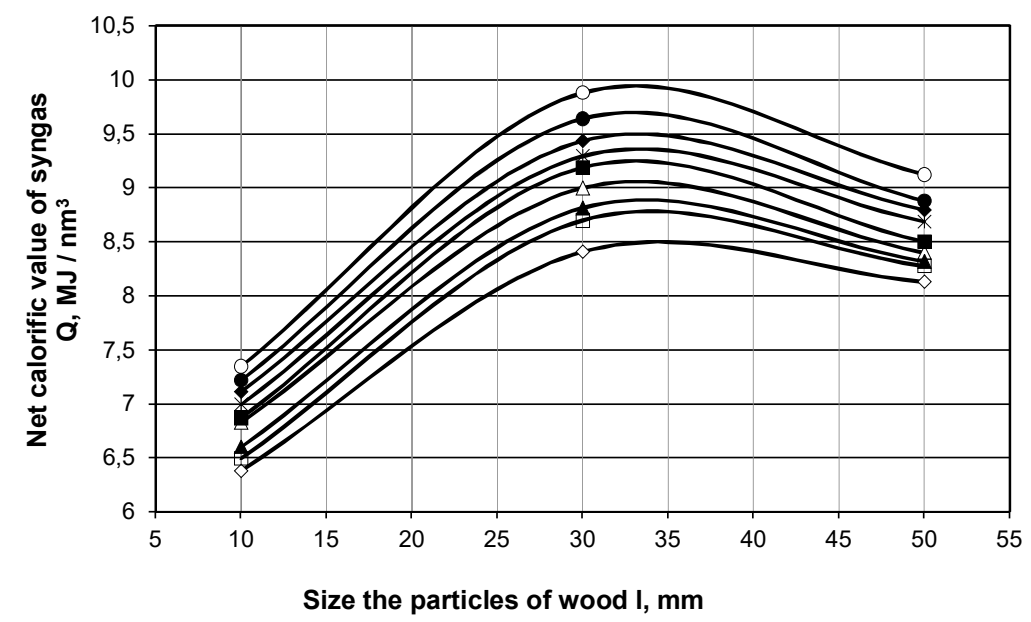

$\neg$ amount of air $40 \mathrm{~m} 3$ / hr., amount of fuel $50 \%$ -amount of air $40 \mathrm{~m} 3 / \mathrm{hr}$., amount of fuel $100 \%$ $-\infty$ amount of air $65 \mathrm{~m} 3 / \mathrm{hr}$., amount of fuel $75 \%$ 工amount of air $90 \mathrm{~m} 3 / \mathrm{hr}$., amount of fuel $50 \%$

$\neg-$ amount of air $40 \mathrm{~m} 3 / \mathrm{hr}$., amount of fuel $75 \%$ *amount of air $65 \mathrm{~m} 3 / \mathrm{hr}$., amount of fuel $50 \%$ $\rightarrow$ amount of air $65 \mathrm{~m} 3 / \mathrm{hr}$., amount of fuel $100 \%$ -amount of air $90 \mathrm{~m} 3 / \mathrm{hr}$., amount of fuel $100 \%$

Fig. 1. Dependence of synthesis gas net calorific value on particle size of chopped wood during pine wood gasification

During the wood gasification (pine) with decreasing particle size from $50 \mathrm{~mm}$ to $30 \mathrm{~mm}$, gas temperature at the outlet of the gasifier decreased. The rate of gasification process increased, which eventually led to a significant increase in productivity a gas generator and to a significant increase in the output of wood gasification of liquid products while increasing net calorific value of synthesis gas. Increased wood chopping leads to an increase in the surface, providing a significant heating rate of particles of wood and allocation of decomposition products on its surface. But with decreasee in the timber particle size from $30 \mathrm{~mm}$ to $10 \mathrm{~mm}$, we could observe decrease in net calorific value of synthesis gas because of the high density of fuel layer which in turn reduces the intensity of the gasification process.

As a result of experimental research [4] using B-plan $\left(\mathrm{B}_{3}\right)$ dependence of the net calorific value of synthesis gas $\left(Q_{u}^{p} \mathrm{MJ} / \mathrm{m}^{3}\right)$, for the process of wood gasification on such factors as: size of the wood particles $1=10,30,50 \mathrm{~mm}$; amount of air $\mathrm{G}=40,65,90 \mathrm{~nm}^{3} / \mathrm{hr}$; amount of fuel in the gasifier reactor $\mathrm{q}=50,75,100 \%$ has been established.

Calculation of the regression coefficients $b_{i j}$, Cochran criterion $G_{p}$ and Fisher criterion $F_{p}[5-8]$ for pine wood are provided in Table 2 .

Table 2. The results of calculation of the regression coefficients, Cochran and Fisher criterions

\begin{tabular}{|c|c|c|c|c|c|c|c|c|c|c|c|c|c|}
\hline $\mathrm{b}_{0}$ & $\mathrm{~b}_{1}$ & $\mathrm{~b}_{2}$ & $\mathrm{~b}_{3}$ & $\mathrm{~b}_{11}$ & $\mathrm{~b}_{22}$ & $\mathrm{~b}_{33}$ & $\mathrm{~b}_{12}$ & $\mathrm{~b}_{13}$ & $\mathrm{~b}_{23}$ & $\mathrm{G}_{\mathrm{r}}$ & $\mathrm{G}_{\mathrm{p}}$ & $\mathrm{F}_{\mathrm{T}}$ & $\mathrm{F}_{\mathrm{p}}$ \\
\hline 9.73 & 0.87 & 0.14 & 0.11 & -1.50 & -0.52 & -0.27 & -0.02 & -0.01 & 0.02 & 0.48 & 0.095 & 2.5027 & 0.2554 \\
\hline
\end{tabular}

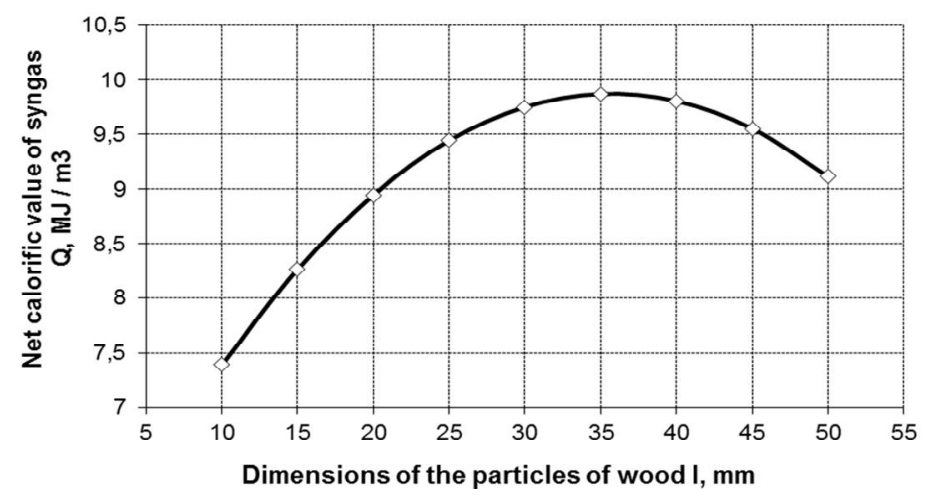

Fig. 2. Dependence of heat of synthesis gas combustion on chopped wood size determined by regression equation with the given amount of air $\left(\mathrm{G}=70 \mathrm{~m}^{3} / \mathrm{hr}\right.$.) and the amount of wood in the gasifier reactor $(\mathrm{q}=80 \%)$ 
As a result of $\mathrm{B}_{3}$-plan implementation, mathematical description of the object in a second order polynomial was obtained:

$$
\begin{aligned}
& Q=-1,5562+0,2726 \cdot l+0.11256 \cdot G+0.06772 \cdot q-0.00375 \cdot l^{2}-0.000832 \cdot G^{2}- \\
& -0.000432 \cdot q^{2}-0.00004 \cdot l \cdot G-0.00002 \cdot l \cdot q+0.000032 \cdot G \cdot q
\end{aligned}
$$

Table 2 shows that $\mathrm{G}_{\mathrm{p}} \leq \mathrm{G}_{\mathrm{T}}(0,095 \leq 0,48)$, experiments can be considered reproducible.

$\mathrm{F}_{\mathrm{p}} \leq \mathrm{F}_{\mathrm{T}}(0,2554 \leq 2,5027)-$ the model is considered adequate and can be used to describe the object.

\title{
5. Conclusions
}

The degree of wood chopping has been shown to significantly affect the gasification process. A significant increase in wood particle size $(l>50 \mathrm{~mm})$ leads to a decrease in the intensity of wood gasification process. During the gasification of wood chips of various degree of shredding, liquid products output changes (the smaller the wood particles the greater the output of total resins of absolutely dry wood weight). The obtained regression equation could be the basis for the process under study and rational process control. With equation of dependence of inputs on the original setting, we can predict every possible parameter for the estimation of the process under study at any values of the factors that are between the upper and lower levels.

\section{References}

[1] Lyamin V. A. Effect of chipping of wood on the output of liquid products of gasification / V. A. Lyamin, A. Nemkin // Journal "Wood chemical industry". - M., 1940. - No. 8 - P. 34-38 (in Russian).

[2] Lyamin V. A. Gasification of small chips of varying humidity / V. A. Lyamin // Journal "The hydrolysis and resin industry". - 1962. No. 8. - P. 8-11. (in Russian).

[3] Ukraine patent for utility model number 38952, INC C10J 3/00. Gas generator / S. S. Lys, Y. S. Badera, Y. M. Hnatyshyn; Owner: NLTU Ukraine; Appl. 08.09.2008; Publish. 26.01.2009, Bulletin No. 2 (in Ukrainian).

[4] Lys S.S. Thermal processing of wood by a continuous layer of gaseous fuel / S. S. Lys, Y. S. Mysak // Eastern European Journal of advanced technologies. - Kharkiv, 2012. - No. 3/8 (57). - P. 47-49 (in Ukrainian)

[5] Hrycak S. A. Research in the woodworking : methodical instructions / S. A. Hrycak, O. A. Boyko, A. S. Kushpit. - Lviv, Ukraine UkrDLTU, 2002. - 26 p. (in Ukrainian).

[6] Pizhurin A.A. Fundamentals of modeling and optimization of processes of woodworking / A. A. Pizhurin, M. S. Rosenblit. - A textbook for high schools. - M.: Forestry, 1988. - 296 p. (in Russian).

[7] Pilipchuk M. I. Basic of scientific research / M. I. Pilipchuk, A. S. Grigoriev, V. V. Shostak. - Lviv: Publishing house "Knowledge", 2007. 234 p. (in Ukrainian).

[8] Chaurasia A. Modeling, simulation, and optimization of pyrolysis of biomass / A. Chaurasia, B. Babu // LAP LAMBERT Academic Publishing. $-2011 .-440$ p.

\section{Визначення впливу фракційного складу деревини на газифікацію}

\author{
Степан Лис, Йосиф Мисак, Тарас Кравець
}

\author{
Національний університет «Львівська політехніка», вул. С. Бандери, 12, Львів, 79013, Україна
}

\section{Анотація}

Теплотворна здатність синтез-газу, отримуваного в результаті газифікації палива, може змінюватися залежно від різних факторів. Основними факторами, які впливають на газифікацію є фракційний склад деревини; кількість повітря, поданого в камеру газифікації; висота активного шару і низки інших факторів, залежних від палива, яке газифікується, і параметрів газифікатора. Будь-яку деревину для подальшого термічного перероблення потрібно подрібнити. Залежно від виробничої необхідності деревину подрібнюють до технологічної тріски різних фракцій рубильними машинами (іх ще називають деревними дробарками, шредерами). Вибір рубильної машини залежить від виробничої необхідності. Сучасні рубильні машини дають змогу робити тонке налаштування вихідного матеріалу за розміром деревини. Зважаючи на дефіцит і ціну енергоносіїв, першочерговим стає використання подрібнених деревних відходів як палива для газогенераторних установок та котлів на твердому паливі.

Ключові слова: теплотворна здатність синтез-газу; газогенераторні установки; газифікація деревини; фракційний склад деревини. 